\title{
Thermo-economic approach for absorption air condition onboard high-speed crafts
}

\author{
Ibrahim S. Seddiek ${ }^{1}$, Mosaad Mosleh ${ }^{2}$ and Adel A. Banawan ${ }^{2}$ \\ ${ }^{1}$ Department of Marine engineering, Faculty of Maritime Studies, King Abdul-Aziz University, \\ Jeddah, Kingdom of Saudi Arabia \\ ${ }^{2}$ Department of Marine Engineering and Naval Architecture, Faculty of Engineering- \\ Alexandria University-Alexandria, Egypt
}

\begin{abstract}
High-speed crafts suffer from losing a huge amount of their machinery energy in the form of heat loss with the exhaust gases. This will surely increase the annual operating cost of this type of ships and an adverse effect on the environment. This paper introduces a suggestion that may contribute to overcoming such problems. It presents the possibility of reusing the energy lost by the ships' exhaust gases as heating source for an absorption air condition unit onboard high-speed crafts. As a numerical example; the proposed method was investigated at a high-speed craft operating in Red Sea between Egypt and the Kingdom of Saudi Arabia. The results obtained are very satisfactory. It showed the possibility of providing the required ship's air condition cooling load during sailing and in port. Economically, this will reduce the annual ship's operating cost. Moreover, it will achieve a valuable reduction of ship's emissions.
\end{abstract}

KEY WORDS: Absorption air condition; Energy conservation; High speed craft; Fuel saving; Fuel cost; Ships emissions; International Maritime Organization (IMO); Thermo-economic.

\section{ABBRIVIATION}

$\begin{array}{llll}\text { AAC } & \text { Absorption air condition } & \text { HCF } & \text { Hydrochlorofluoro } \\ \text { COP } & \text { Coefficient of performance } & \text { HSC } & \text { High-speed craft } \\ \text { CV } & \text { Calorific value } & \text { Li-Br } & \text { lithium bromide } \\ \text { C.R.F } & \text { Capital cost recovery } & \text { IMO } & \text { International Maritime Organization } \\ \mathrm{CO}_{2} & \text { Di-oxide } & \text { MEPC } & \text { Maritime Environmental Protection Committee } \\ \text { EEDI } & \text { Energy Efficiency Design Index } & \text { NOx } & \text { Nitrogen Oxides } \\ \text { FSB } & \text { Fuel saving during Ship Berthing } & \text { P.M } & \text { Particular Matters } \\ \text { FSS } & \text { fuel saving during Ship Sailing } & \text { SOx } & \text { Sulfur Oxide } \\ \text { Fp } & \text { Fuel price } & \text { TFS } & \text { Total fuel saving } \\ \text { HC } & \text { Hydrocarbons } & & \end{array}$

Corresponding author: Ibrahim S. Seddiek

e-mail: isibrahim@kau.edu.sa 


\section{NOMENCLUTURES}

\begin{tabular}{|c|c|c|c|c|c|}
\hline$A A C_{C C}$ & Absorption air condition capital cost & $(\$ / k W)$ & $\mathrm{O} \& \mathrm{M}_{\mathrm{C}}$ & Operating and maintenance cost & $(\$ / k W)$ \\
\hline$A / F$ & Air fuel ratio & - & $Q_{\text {flow }}$ & Heat flow in pipe (1-2) & $(\mathrm{kJ} / \mathrm{s})$ \\
\hline BHP & Brake horse power & $(k W)$ & $Q$ & Heat transferred from hot stream to & \\
\hline$C A$ & Annual cost & $(\$)$ & & cold stream & $(\mathrm{kJ} / \mathrm{s})$ \\
\hline$C_{i}$ & Capital cost & $(\$)$ & $Q_{\max }$ & maximum heat transfer in an exchanger & $(\mathrm{kJ} / \mathrm{s})$ \\
\hline$C_{p e x}$ & Exhaust gas specific heat & $(k J / k g . k)$ & $\operatorname{Re}$ & Reynolds number & - \\
\hline$C_{p w}$ & Fresh hot water specific heat & $(k J / k g . k)$ & $\operatorname{Pr}$ & Prandtl number & - \\
\hline$C_{L}$ & Unit cooling load & $(k W)$ & $R_{c}$ & Heat ratio & - \\
\hline$d_{i}$ & Inner exhaust pipe diameter & $(m)$ & $\sum R_{t h}$ & Thermal resistance & $\left({ }^{o} \mathrm{C} / \mathrm{K}\right)$ \\
\hline$d_{o}$ & Outer exhaust pipe diameter & $(m)$ & $r_{i}$ & inner pipe radius & $(m)$ \\
\hline$E_{f}$ & Emission factor & $(g / k W h)$ & $r_{o}$ & Outer pipe radius & $(m)$ \\
\hline E & Emission quantity & (ton) & $r_{s}$ & insulation pipe radius & $(m)$ \\
\hline$h_{i}$ & Inner pipe convection heat transfer & & $S F C_{g}$ & Generator specific fuel consumption & $(g / k W h)$ \\
\hline & coefficient & $\left(W / m^{2} \cdot k\right)$ & $T_{1}$ & Engine exhaust gas outlet temperature & $(K)$ \\
\hline$h_{o}$ & Outer pipe convection heat transfer & & $T_{2}$ & Exhaust temp. before heat exchanger & $(K)$ \\
\hline & coefficient & $\left(W / m^{2} . k\right)$ & $T_{3}$ & Exhaust temp. after heat exchanger & $(K)$ \\
\hline$H \cdot E_{C}$ & Heat exchanger cost & $(\$)$ & $T_{5}$ & heat exchanger's inlet hot water & \\
\hline $\mathrm{I}_{\mathrm{FP}}$ & Yearly increment of fuel price & $\%$ & & temperature & $(K)$ \\
\hline i & Annual interest & $\%$ & $T_{6}$ & fresh water outlet from the ARU & \\
\hline ins $_{\mathrm{cp}}$ & Installation cost percentage & $\%$ & & generator & $(K)$ \\
\hline$k_{\mathrm{p}}$ & Exhaust Pipe thermal conductivity & $(W / m \cdot k)$ & $T_{7}$ & Heat exchanger fresh water outlet & \\
\hline $\mathrm{k}_{\mathrm{s}}$ & Exhaust pipe insulation thermal & & & temperature & $(K)$ \\
\hline & conductivity & $(W / m \cdot k)$ & $T_{s}$ & Exhaust pipe insulation temperature & $(K)$ \\
\hline$L_{E p}$ & Saved electric load at berth & $(k W)$ & $T_{a m b}$ & Ambient temperature & $(K)$ \\
\hline$L_{E s}$ & Saved electric load during sailing & $(k W)$ & $t_{p}$ & Port time & (h) \\
\hline$\dot{m}_{g}$ & Exhaust gas flow rate & $(k G / s)$ & $t_{s}$ & Sailing time & (h) \\
\hline$\dot{m}_{f}$ & Engine fuel rate consumption & $(k G / s)$ & $\varepsilon$ & Heat exchanger effectiveness & $\%$ \\
\hline $\mathrm{m}_{\mathrm{w}}$ & Hot water flow rate & $(k G / s)$ & $\lambda$ & Excess air ratio & - \\
\hline $\mathrm{n}$ & The expected ship working years & years & $\mu$ & Exhaust gas viscosity & $\left(N . s / m^{2}\right)$ \\
\hline$N_{u}$ & Nusselt number & $(k G / s)$ & $\theta$ & engine load & - \\
\hline$N_{t u}$ & Number of transfer unit & - & $\theta_{p}$ & Engine load percentage & $\%$ \\
\hline
\end{tabular}

\section{INTRODUCTION}

Commercial ships burn a huge amount of fuel, which means considerable increasing in both operating cost and amount of emissions. The only traditional solution for this problem is fuel saving. Over $90 \%$ of fuel is burned to produce the power required to drive the ship. But this is definitely not sufficient when looking for energy saving on vessels carrying passengers such as high-speed ships. It was shown by Hall (2010) that in these ships, other energy consuming sources are considered, especially those while at port. Several studies carried out by Wartsila (2010), (Corbett et al., 2009) and Munk (2006), aiming to minimize the fuel consumption, have demonstrated different methods to achieve this goal. Unfortunately, most of these methods are not suitable for high-speed passenger crafts (HSCs) due to the nature of their operations. Therefore, it is necessary to search for new energy conservation methods that can be applied onboard HSCs. One way to find a new solution to this problem is to study the viability of applying an absorption air conditioning (AAC) unit to provide the required cooling load for the air conditioning system instead of the traditional compression vapor system.

\section{ABSORPTION REFRIGERATION SYSTEM DESCRIPTION}

Absorption cycles are primarily heat-operated cycles in which heat is pumped with a minimum of work input compared 
with the compression vapor cycle (ASHRAE, 1997, chapter1). The two great advantages of this type of cycle in comparison to other cycles with similar product are: no large rotating mechanical equipment is required and it can utilize low-grade heat energy, such as geothermal, waste heat and solar energy to provide the cooling load (ASHRAE, 2010, chapter18). On the other hand, one of the disadvantages of absorption cycle is the lower coefficient of performance (COP) compared to compression vapor cycle (Manzela et al., 2010; Kaynakli and Kilic, 2007; De Lucas et al., 2004). Absorption Refrigeration Units (ARUs) are commercially available today in two basic configurations. One for application above zero ${ }^{\circ} \mathrm{C}$, (Primarily air conditioning), the cycle uses lithium bromide ( $\mathrm{Li}-\mathrm{Br})$ as the absorbent and water as the refrigerant. The other for application below zero ${ }^{0} \mathrm{C}$, (primary refrigerating) an ammonia / water $\left(\mathrm{NH}_{3}-\mathrm{H}_{2} \mathrm{O}\right)$ cycle is employed with ammonia as the refrigerant and water as the absorbent (Harbach, 2005).

\section{Absorption air condition system configuration}

There are three configurations of Li-Br system: single effect, double effect, and half effect. The main differences among the previous systems are COP value and heating range. It was shown by Masheiti and Agnew (2010) that single effect type is suitable for waste heat application while half effect may be more effective in case of geothermal and solar application. The basic single-effect cycle includes: generator, condenser, evaporator, and absorber, in addition to a liquid-liquid heat exchanger (Sdrubali and Grignaffini, 2005), which is presented in Fig. 1. As shown in the figure, the generator utilizes a heat source (hot water) to vaporize the dilute lithium bromide solution. The water vapor that is released travels to the condenser where it is condensed back into a liquid, and transferring the heat to the cooling tower water. Once condensed, the liquid refrigerant is distributed over the evaporator tubes, removing the heat from the chilled water, which will be used for air cooling, and vaporizing the liquid refrigerant. The concentrated lithium bromide absorbs the refrigerant vapor solution from the evaporator and dilutes itself. The dilute lithium bromide solution is then pumped back to the generator where the cycle starts again.

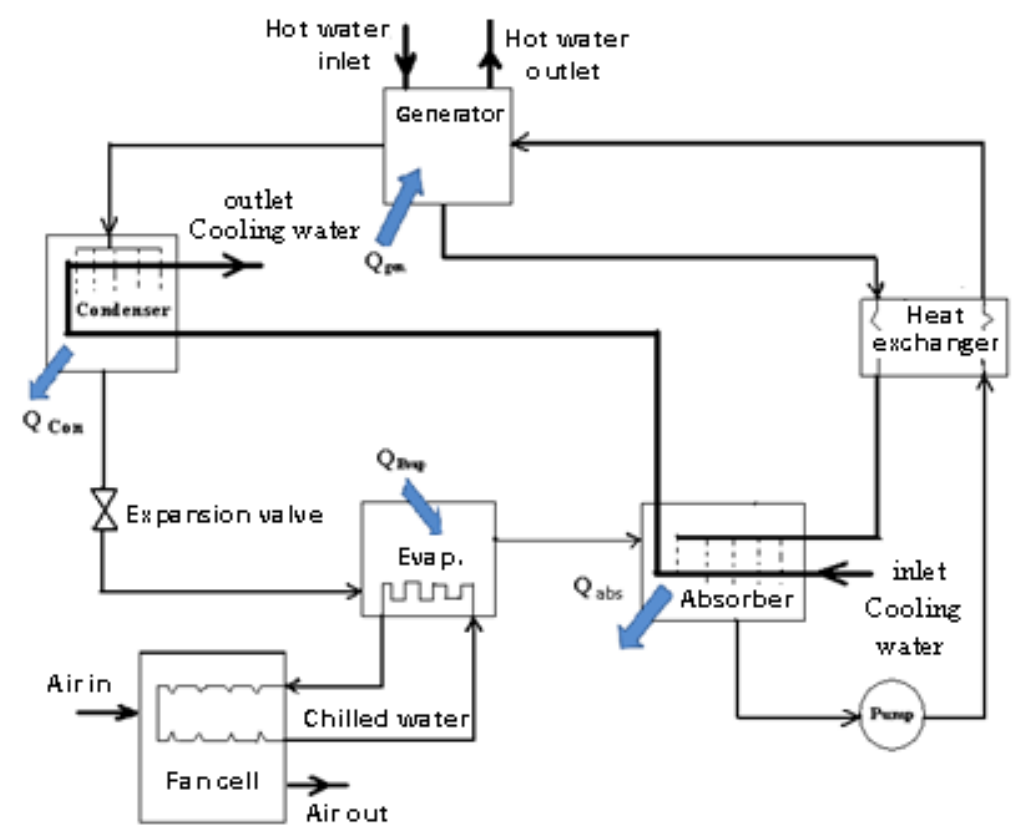

Fig. 1 Single effect an absorption system components using waste heat.

\section{APPLYING ABSORPTION AIR CONDITION SYSTEM ONBOARD HIGH-SPEED CRAFTS}

Most of the researches carried out to investigate the applicability of using the ARUs are focusing on in-land applications, while just few researches have been conducted concerning applying such a system in marine applications (Seara et al., 1998; Wang and Wang, 2005). The most important outcomes from these researches are that the adaptability of the ARU system onboard ships depends on some parameters that affect the viability of the absorption system such as electric load demand, heat source availability and its range, as well as some economical aspects.Thus, the core of this paper is to study the effect of the 
above mentioned parameters on the applicability of this concept onboard HSCs, and to verify its environmental and economical benefits. One of the main reasons to propose applying of AAC Onboard High-Speed Crafts is the fact that HSCs use four-stroke diesel engines as prime-movers, which use light diesel oil without utilizing exhaust gases from the main engines for steam generation, as that happened in the case of two stroke engine. It was shown by Domkundwar (2004) that in case of four stroke diesel engines exhaust gases energy present about $20 \%$ to $30 \%$ of the total input energy, thus a huge amount of fuel energy content is wasted. Consequently, the exhaust gases could be used as an indirect heat source for AAC during ship sailing. Moreover, HSCs stay for a long period at berth, while still in need to operate the air conditioning system for crew comfort, cooling the navigation instruments and cool the accommodation spaces before the departure. In this case, the cooling load could be provided using the exhaust gases from the electric diesel generators to operate the AAC unit.

\section{Absorption air condition model description onboard high-speed crafts}

The model used here consists of two main parts. The first part presents the ARU, which will provide the required cooling load, it different from one case to another. The second part of this model shows the various connections attached to the absorption unit in order to obtain the required inlet hot water temperature for ARU, which is considered the outlet of the second part as shown in Fig. 2. The required inlet hot water temperature for ARU, will be obtained by heating fresh water using the engines' exhaust gas heat losses. ARU unit will provide a very low temperature for shelled water. The air fan will suction the air from outside or circulation branches, and passing it thought the shelled water pipes. The air will be cooled and pumped to the ship's distributer sectors to provide the required air conditioning.

Moreover, the figure shows the concept of utilizing AAC during both ship's sailing and at the berth. During sailing mode, valves ( $a, c \& d$ ) will be opened and valve (b) closed. In case of port mode, valves (b \& c) will be opened and valves (a \& d) closed.

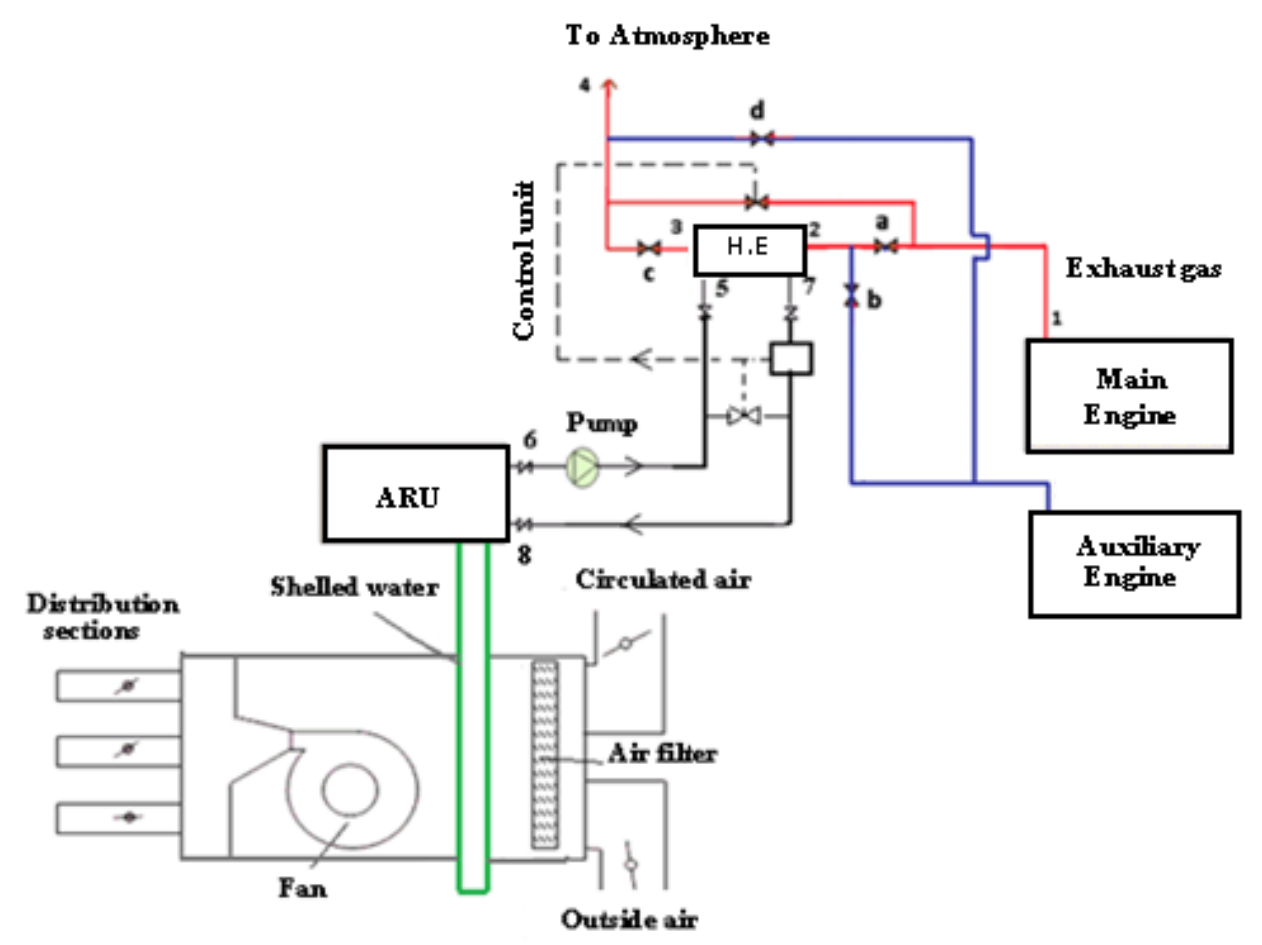

Fig. 2 The proposed absorption air condition model arrangements onboard high speed craft.

As shown in Fig. 2, the value of heat exchanger's outlet fresh water temperature $\left(T_{7}\right)$ is nearly equal to fresh water inlet temperature of ARU generator $\left(T_{8}\right)$. This temperature plays a main role in the possibility of applying AAC onboard ship, will depend largely on the heat of the engine exhaust gas outlet and system's specification and arrangements.

Through the exhaust gas pipe (1-2) there is a loss of exhaust gas temperature due to radiation. Although it seems small but it 
cannot be neglected. The value of exhaust gas temperature inlet heat exchanger $\left(T_{2}\right)$ could be calculated as follow (for derived see appendix 2-a):

$$
\begin{gathered}
T_{2}=T_{1}-\frac{\left(T_{1}-T_{a m b}\right)}{\left[\dot{m}_{g} C_{p g}\right]\left[\left(\frac{1}{\pi d_{i} L h_{i}}\right)+\left(\frac{\ln \frac{r_{o}}{r_{i}}}{2 \pi L k_{p}}\right)+\left(\frac{\ln \frac{r_{s}}{r_{o}}}{2 \pi L k_{s}}\right)+\left(\frac{1}{\pi d_{o} L h_{o}}\right)\right]} \\
T_{1}=f(\theta) \\
\dot{m}_{g}=\dot{m}_{f}(1+[A / F] \lambda)
\end{gathered}
$$

$\left(T_{1}\right)$ is the engine's exhaust gas outlet temperature, $(\theta)$ engine load, $\left(\dot{m}_{g}\right)$ is exhaust gas flow rate, $\left(\dot{m}_{f}\right)$ engine fuel rate consumption, $(A / F)$ fuel air ratio and $(\lambda)$ excess air ratio. In addition, $T_{a m b}, L, d_{i}, d_{o}, r_{o}, r_{i}$ and $r_{s}$ are ambient temperature, exhaust pipe length, exhaust gas inner pipe diameter, outer pipe diameter, outer pipe radius, inner pipe radius and outer radius with insulation, while $C_{p g}, h_{i}, h_{o}, k_{p}$ and $k_{s}$ are, exhaust gas specific heat, inner heat convention, outer heat convention, pipe thermal conductivity and insulation thermal conductivity respectively.

Through the heat exchanger (2-3) there is a loss of exhaust gas temperature due to the heat transfer from the exhaust side to the water side. By applying the heat transfer concept between the exhaust side and the water side, the value of hot water outlet temperature $\left(T_{7}\right)$ could be calculated as follows (for derived see appendix 2-b):

$$
T_{7}=R_{c} \varepsilon\left(T_{2}-T_{5}\right)+T_{5}
$$

where $\varepsilon, T_{5}$, and $R_{c}$ are counter flow heat exchanger effectiveness, heat exchanger's inlet hot water temperature, which is nearly equal to fresh water outlet from the $\operatorname{ARU}$ generator $\left(T_{6}\right)$, and heat ratio respectively.

$$
\varepsilon=\frac{1-e^{-N_{t u}\left(1-R_{c}\right)}}{1-R_{c} e^{-N_{t u}\left(1-R_{c}\right)}}
$$

Value of Number of transfer unit $\left(N_{t u}\right)$, and $\left(R_{c}\right)$ could be estimated by the thermodynamic equations listed by Holman (2002).

A thermodynamic modeling is constructed to facilitate obtaining $\left(T_{7}\right)$, at various conditions such as engine load percent, heat exchanger effectiveness, inlet fresh water temperature, etc. The software used is the Engineering Equations Solver (EES) (Commercial version) for both main engines and electric diesel generator, where the thermodynamic properties of the substances under study can be easily obtained using the built-in functions and data.

\section{CASE STUDY: APPLICATION OF ABSORPTION AIR CONDITION ONBOARD HIGH-SPEED CRAFTS WOR- KING AT THE RED SEA}

In recent years, the number of short-voyage passenger ships sailing in the Red Sea area has increased. There is no doubt that these ships have contributed to develop maritime transport in this area. On the other hand, it was shown by (Banawan et al., 2010) that the high power of these ships contributed to the increasing gaseous emission rate and caused a detrimental effect on the environment in this area.

The present paper discusses the viability of applying AAC unit using the waste heat from exhaust gases of one of the highspeed crafts operating in the Red Sea area, called Alkahera. The ship operates between Hurghada port in Egypt and Duba port in the Kingdom of Saudi Arabia. The ship's technical data is summarized in Table 1. 
Table 1 Ship's technical data (M/V Alkahera sea trial book).

\begin{tabular}{|c|c|}
\hline Ship name & Alkahara \\
\hline Main engine & $4 \times$ MTU 20 V 8000 M71R \\
\hline Maximum continuous rating & $4 \times 7,200 \mathrm{~kW}$ a 1,150 rpm $\pm 1.5 \%$ \\
\hline Service speed & 34 knots \\
\hline Fuel consumption at 90\% MCR & 5,731 Liters $/$ Hour \\
\hline Generating sets & $4 \times$ MAN D2866 LXE LSAM 46.2 VL12,228 $\mathrm{kW}, 1500 \mathrm{RPM}$ \\
\hline Air condition cooling capacity & $250 \mathrm{~kW}$ \\
\hline
\end{tabular}

From the principal heat balance calculations of one of the main engines, the exhaust gases heat losses is about 4,100 kJ/s. It presents about $28.55 \%$ of the total fuel energy content, with higher exergy that could be reused as waste heat recovery for AAC unit. According to the technical data of the case study, the maximum cooling capacity required for air conditioning is about 250 $k W$. This load can be covered using Carrier AAC model 16LJ11, which has the following technical details as shown in Table 2. Consistent with Table 2 the required AAC inlet hot water temperature is $95^{\circ} \mathrm{C}$. Thus, this value will play a main role in the possibility of applying AAC onboard ship.

Table 2 Absorption unit 16LJ11 technical specifications (Carrier company, 2012).

\begin{tabular}{|c|c|}
\hline AAC Model $16 \mathrm{LJ} 11$ & 264 \\
\hline Nominal cooling capacity $(\mathrm{kW})$ & 11.4 \\
\hline Child water & 55 \\
\hline Flow rate $(l / s)$ & 12.27 \\
\hline Pressure drop $(k \cdot P a)$ & 6.7 \\
\hline Inlet temp. $\left({ }^{\circ} \mathrm{C}\right)$ & \\
\hline Outlet temp. $\left({ }^{\circ} \mathrm{C}\right)$ & 17.0 \\
\hline Cooling water & 36 \\
\hline Flow rate $(l / s)$ & 29.4 \\
\hline Pressure drop $(k \cdot P a)$ & 38.4 \\
\hline Inlet temp. $\left({ }^{\circ} \mathrm{C}\right)$ & \\
\hline Outlet temp. $\left({ }^{\circ} \mathrm{C}\right)$ & 86.0 \\
\hline Hot water system & 10.4 \\
\hline Flow rate $(l / s)$ & 31 \\
\hline Pressure drop $(k \cdot P a)$ & 95.0 \\
\hline Inlet temp. $\left({ }^{\circ} \mathrm{C}\right)$ & \\
\hline Outlet temp. $\left({ }^{\circ} \mathrm{C}\right)$ & \\
\hline
\end{tabular}

\section{Viability of absorption air condition system using exhaust gases from main engines}

Table 3 shows the main specification of main engine exhaust gases system and the various collected data. Substitution in equations (1-5), using data calculated according to appendix (1), Fig. 3(a) \& 3(b) produced using EES program. Fig. 3(a) presents the change of $\left(T_{7}\right)$ with engine load at different values of exhaust gas flow percentage and determines the actual amount of exhaust gases needed to achieve the required temperature. Fig. 3(b) illustrates the change of $\left(T_{7}\right)$ with engine load at 
different values of inlet fresh water temperatures. Moreover, Fig. 3(b) shows that the required value of $\left(T_{7}\right)$ will be easy to obtain with increasing value of inlet fresh water temperature.

Table 3 Main engine exhaust gas piping system specifications.

\begin{tabular}{|c|c|}
\hline Data & value \\
\hline Engine load percentage & $85 \%$ \\
\hline$d_{i}$ & $0.30 \mathrm{~m}$ \\
\hline$d_{o}$ & $0.324 \mathrm{~m}$ \\
\hline$d_{s}$ & $0.342 \mathrm{~m}$ \\
\hline$L$ (suitable position) & $20 \mathrm{~m}$ \\
\hline$k_{p}$ & $50\left(\mathrm{~W} / \mathrm{m} .{ }^{\circ} \mathrm{C}\right)$ \\
\hline$k_{s}$ & In range of $(0.1-0.2)\left(\mathrm{W} / \mathrm{m}^{\circ} \mathrm{C}^{\circ} \mathrm{C}\right)$ \\
\hline$T_{a m b}$ & $45{ }^{\circ} \mathrm{C}$ \\
\hline
\end{tabular}

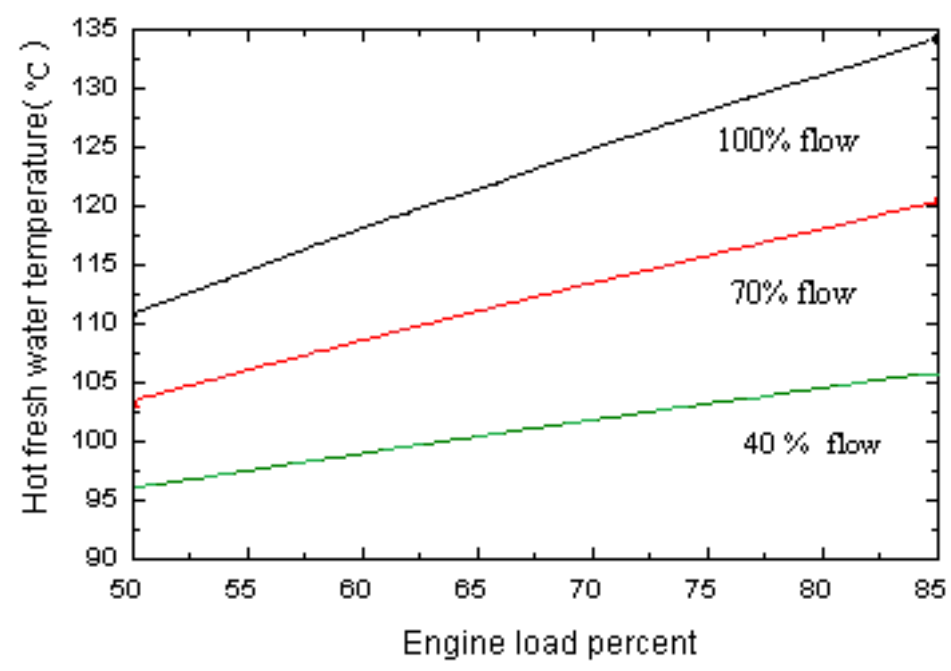

Fig. 3(a) Outlet fresh water temperature Vs engine load at various exhaust gases flow percentage.

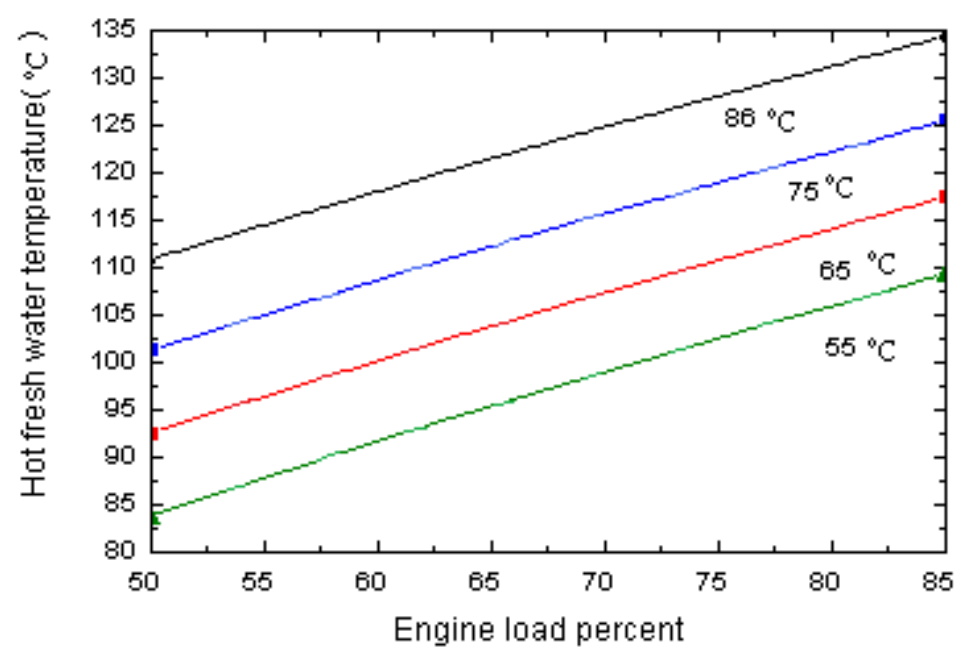

Fig. 3(b) Fresh water outlet temperature Vs engine load at various fresh water inlet temperatures. 
Analyzing the previous figures gives a good indication about the possibility of obtaining a temperature greater than those required, which will be used as a heat source for the AAC unit at engine load above $50 \%$ for different expected operating parameters' conditions. It means that during propulsion there is no problem in getting the cooling load that is required from the basic air conditioning unit, from the exhaust gas of one main engine. So, to obtain the exact temperature, which is nearby $\left(95^{\circ} \mathrm{C}\right)$, this may be achieved by controlling the rate of exhaust gases passing through the heat exchanger. The process is done by using bypass valve and automatic control unit which operates between heat exchanger fresh water outlet side and heat exchanger exhaust gas inlet side as shown in Fig. 2.

\section{Viability of absorption air condition system using exhaust gases from main electric generators}

During ship's maneuvering, where the main engines under variable loads, to avoid the problem of system's preparation; air conditioning can be utilized by using the main electric generators' exhaust gases to operate AAC unit. Regards to application of the proposed system in the ship berthing condition, as ship's engines stop, the system will depend only on exhaust gases coming from electric generator engines, which may be one or two sets according to the ship's operating electric load. Un-necessary air conditioning zones will insulated, thus the produced cooling load from the proposed system could provide the required air temperature for the necessary zones such as navigation area. So, it is recommended to carry any maintenance activity during ship berthing as the air conditioning system could be stopped, especially during the nigh periods. During ship berthing, before ship sailing, the change over from generator engines to main engines should be done gradually according to ( $\left.T_{7}\right)$. In port, the main problem which may face applying this concept is that if there is only one generator set working, the amount of energy stored in the generator exhaust gases will be much less than that found in the main engine exhaust gas. To overcome this problem, a pump with a variable flow rate may be used to commensurate with the required cooling load.

The previous equations will be used also in case of electric generator. The program calculations provide both engine exhaust gas temperature and fresh water flow rate as two main parameters that affect the value of $\left(T_{7}\right)$. Table 4 shows the main system specifications, and the various collected data at $200 \mathrm{~kW}$ generator powering load which presents ship's total electric load without air condition load.

Table 4 Main diesel generator's exhaust gas piping system specifications.

\begin{tabular}{|c|c|}
\hline Data & Value \\
\hline$T_{1}$ & In range of $(300-350){ }^{\circ} \mathrm{C}$ \\
\hline$d_{i}$ & $0.25 \mathrm{~m}$ \\
\hline$d_{o}$ & $0.274 \mathrm{~m}$ \\
\hline$d_{s}$ & $0.292 \mathrm{~m}$ \\
\hline$L$ (suitable position) & $30 \mathrm{~m}$ \\
\hline$\dot{m}_{f}$ & $0.0208 \mathrm{~kg} / \mathrm{s}$ \\
\hline$k_{p}$ & $50\left(\mathrm{~W} / \mathrm{m} .{ }^{\circ} \mathrm{C}\right)$ \\
\hline$k_{s}$ & In range of $(0.1-0.2)\left(\mathrm{W} / \mathrm{m} .{ }^{\circ} \mathrm{C}\right)$ \\
\hline$T_{a m b}$ & $45^{\circ} \mathrm{C}$ \\
\hline
\end{tabular}

Fig. 4(a) shows the change of outlet fresh water temperature with fresh water flow rate at different exhaust gas temperature, taking into consideration that change of exhaust gas temperature may be occurred due to change of ( $\left.T_{a m b}\right)$ or due to malfunction of diesel generator injectors. While Fig. 4(b) demonstrate alteration of outlet fresh water temperature with fresh water flow rate at different heat exchanger effectiveness, which may be effected by another factors such as heat exchanger fouling.

The results obtained using EES program showed that: at port, according to the operating parameters of the auxiliary diesel generator at $200 \mathrm{~kW}$; fresh water flow rate of between ( 2 to $2.25 \mathrm{~kg} / \mathrm{s}$ ) could achieve the required hot fresh water temperature at 
the expected various operating conditions. In this case a cooling load in range of (50 to 60) $\mathrm{kW}$ could be obtained. This load is considered enough for providing air conditioning to the places of interest, such as bridge zone where there is navigational instruments and public and crew accommodation areas, as well as providing air conditioning for passenger accommodation before ships sailing.

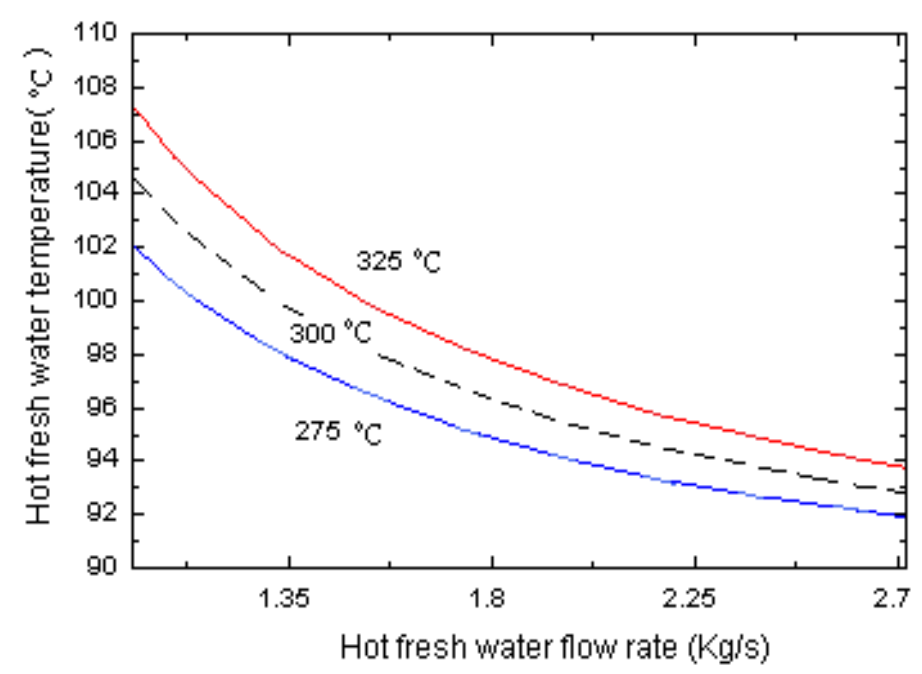

Fig. 4(a) Outlet fresh water temperature Vs fresh water flow rate at different exhaust gas temperatures.

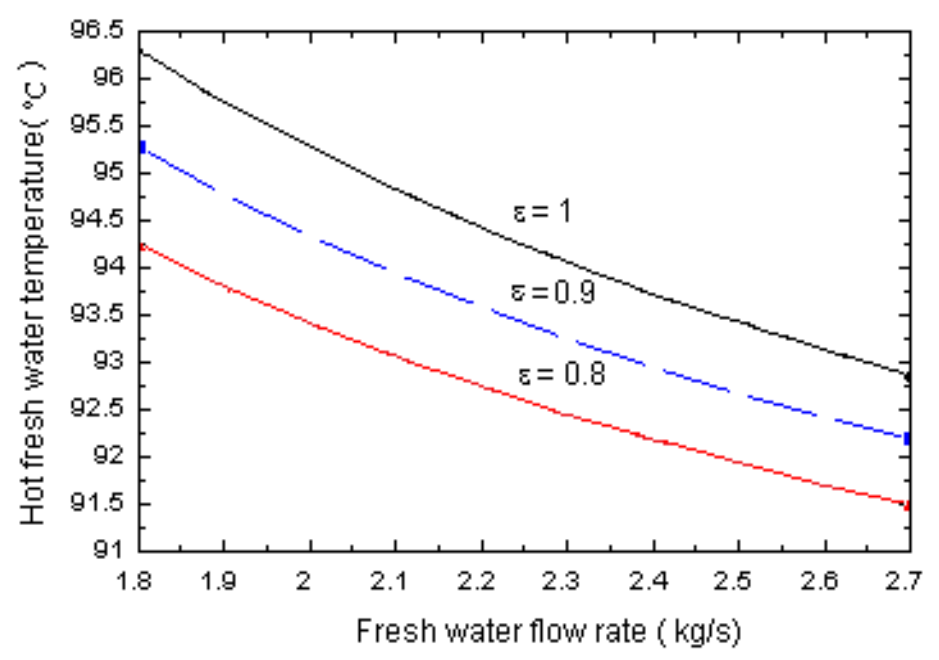

Fig. 4(b) Hot fresh water temperature Vs fresh water flow rate at different heat exchanger effectiveness.

\section{TECHNICAL CONSIDERATIONS FOR APPLYING ABSORPTION AIR CONDITION ONBOARD HIGH SPEED CRAFTS}

Some technical issues should be taken into consideration, which may present barriers accompany this proposal, such as effect of the unit's weight on ship's behavior and the required space for AAC unit onboard ship. Moreover, the importance of ship's working area from the viewpoint of weather condition such as sea water temperature, as increasing of sea water temperature will reduce the value of COP. In addition, there is another problem may appear in form of cooling load shortage, which may happen during ship's maneuvering or in case of AAC unit malfunction. Related to the mentioned case study; fortunately, the chosen AAC unit has both light weight and low volume, consequently will haven't a sensible effect on ship's characteristics. So the unit's deterioration due to sea water will very limited where the measured sea water temperature at the Red Sea area being below the desired value. As well as, it is suggested that the AAC unit should be provided by one of the compression vapor units, which a part of the basic air conditioning unit; or installed small compression vapor unit in case of the new ship as a 
back- up unit in case of system maul-faction to supply the essential cooling load until system re-stating. Over and above, it is recommended that a periodical maintenance operation, especially for heat exchanger should be occurred to prevent the system's maul-faction due exhaust gas piping fouling.

\section{ABSORPTION AIR CONDITION AND ECONOMICAL ANALYSIS}

The economic feasibility of this proposal depends mainly on both the fuel cost which could be saved and the unit installation cost onboard ship. The total fuel saving (TFS ) in case of applying AAC concept onboard high speed ships is a sum of the amount of fuel saved during sailing ( FSS ) and the amount of fuel saved at berth ( FSB ).Value of (FSS) depends on saved electric load during the trip $\left(L_{E s}\right)$ in $(k W / h)$, generator specific fuel consumption $\left(S F C_{g}\right)$ in $(g / k W h)$ and total sailing time per year $\left(t_{s}\right)$ in $(h)$. In the same manner, value of (FSB) depends mainly upon the saved electric load at berth $\left(L_{E p}\right)$ in $(k W / h)$, $\left(S F C_{g}\right)$ in $(g / k W h)$ and ship berthing time $\left(\mathrm{t}_{\mathrm{p}}\right)$ year in $(h)$. Thus, value of TFS could be estimated as follows:

$$
T F S=S F C_{g}\left(L_{E s} \cdot t_{s}+L_{E p} \cdot t_{p}\right)
$$

There is no doubt that the actual estimation of TFS will shows a limited variation due to the external variables such as weather conditions and number of trips per year.

Related to fuel cost, during the last few years, bunker prices have been raised considerably. Thus, an increasing of bunker price in shipping, especially engaged in short voyage, affects earnings negatively (Notteboom and Vernimmen, 2009). Fuel price trend during the last decade showed dramatically changes (Bunker world, 2012), which indicates that there is an expectation of increment in the next years due to the continuing increment in fuel consumption, taking into consideration that there are other factors affecting this matter such as the political events. The Fuel cost saving ( FCS ) will depend on three main factors including: the amount of fuel saved, fuel prices, and fuel price yearly increment. This may be expressed in the following equation:

$$
F C S=T F S \cdot F_{p}\left[1+I_{F P}\right]^{n}
$$

where $\left(F_{p}\right),(\mathrm{n})$ and $\left(\mathrm{I}_{\mathrm{FP}}\right)$ are fuel price $(\$ / t)$, the expected ship working years after AAC unit installed and yearly increment of the fuel price, respectively.

\section{Absorption air condition unit installation cost}

Total installation cost of any absorption air condition system depends upon three main variables; namely the initial cost, the operating cost and finally the maintenance cost. The initial cost includes, in addition to the purchase and installation of the systems, the various sub systems necessary for effective operation. Operating cost includes the cost of electricity, supplies, water and materials while the maintenance cost is difficult to quantify because it depends upon a large number of variables such as local laborcost, the age of the equipment, time of operation, etc (Elsafty and Al-Daini, 2002). Based on data collected from actual projects utilizing the same air condition concept for land application and quotations asked from absorption air condition manufactures; value of initial, operating and maintenance cost may be considered as shown in Table 5, which could be used to estimate the total cost of the proposed AAC unit as shown in equation (8).

$$
\text { Total Unit Cost }=\left[A A C_{C C} \cdot C_{L}\right]\left[1+i n s_{c p}\right]+C_{L} \sum_{x=1}^{x=j} O \& M_{C}+H \cdot E_{C}
$$

$\left(A C C_{C C}\right)$ is absorption air condition capital cost in $(\$ / k W),\left(C_{L}\right)$ is unit cooling load in $(k W),\left(i n s_{c p}\right)$ is installation cost 
percentage, $\left(O \& M_{C}\right)$ is operating and maintenance cost in $(\$ / \mathrm{kW}),(j)$ indicates about number of the various operating and maintenance items and $\left(H \cdot E_{C}\right)$ is heat exchanger cost in $(\$)$.

Table 5 Absorption air condition unit cost analysis.

\begin{tabular}{|c|c|c|}
\hline Item & Specific cost & Total cost \\
\hline AAC capital cost & $(500-700) \$ / k W$ & $(132,000-185,000) \$$ \\
\hline Installation cost & $12 \%$ Capital cost & $(15,840-22,200) \$$ \\
\hline Heat exchanger cost & & $10,572 \$$ \\
\hline Operating cost & $(6-8) \$ / k W$ & $1584-2112$ \\
\hline Maintenance cost & $(0.0066-0.008) \$ / k W h$ & $(15,507-18,796)$ \\
\hline
\end{tabular}

Table 5 presents the various costs of the proposed system. The capital, installation and operating maintenance, and Heat exchanger costs are based on data collected from the previous published researches and actual projects which carried out in this point (Elsafty and Al-Daini 2002; Florides et al., 2003; CHP Application Center, 2011).

Thus, both savings and cost value could be used to determine the preliminary economic aspects. This may be done using the annual money saving method. It was shown by Hunt and Butman (1995) that in this method, savings depend on the expected average value of ship age after conversion to the new air condition system and the capital recovery factor (CRF) with variable interest according to the following equation.

$$
C A=C_{i} \cdot\{C \cdot R \cdot F\}
$$

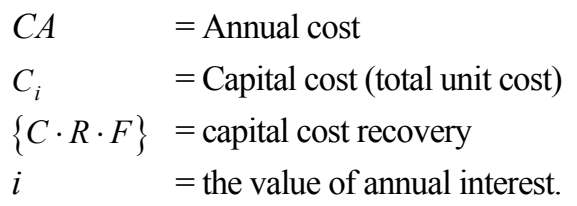

$$
\{C . R . F\}=i \cdot\left[\frac{(1+i)^{n}}{(1+i)^{n}-1}\right]
$$

It was publicized by Det Norske Veritas (2000) that according to the classification society rules, the main class requirements and the additional requirements given in the Rules for High Speed, Light Craft and Naval Surface Craft are based on a target design life of the craft for twenty years with the attempts to extent this target. Consequently, related to the present case study, the expected ship's working years could be about sixteen years from now. As a result of the shortage of actual minor supplement items cost, it should be noted that the use of assumptions and general figures is inevitable for this type of cost-benefit analysis, and that the result therefore should be seen as best estimates.

Using the data collected about M/V Alkahera regards to sailing and berthing periods, and fuel prices; Fig. 5 presents various scenarios for the economical analysis in case of applying the proposed system onboard M/V Alkahera. Cases I and II show the effect of unit capital cost on the number of years needed to achieve the economic demand. Cases III and VI show number of years needed for cost recovery in case of applying AAC for both sailing and berthing together or for berthing only, respectively. The results seem valuable from the viewpoint of economic, giving a period of about five to six years in the worst case for total cost recovery, which is being very short compared to the expected ships' age. It is clear that as ship's working year's increase, the net cost saving increase, which will contributein reducing of the total ship's operating cost. At working years of 16 years the proposed system may be achieve cost fuel saving of about 337,380 and 143,360 (\$/year) in case of sailing and berthing condition or in berthing condition only, respectively. 


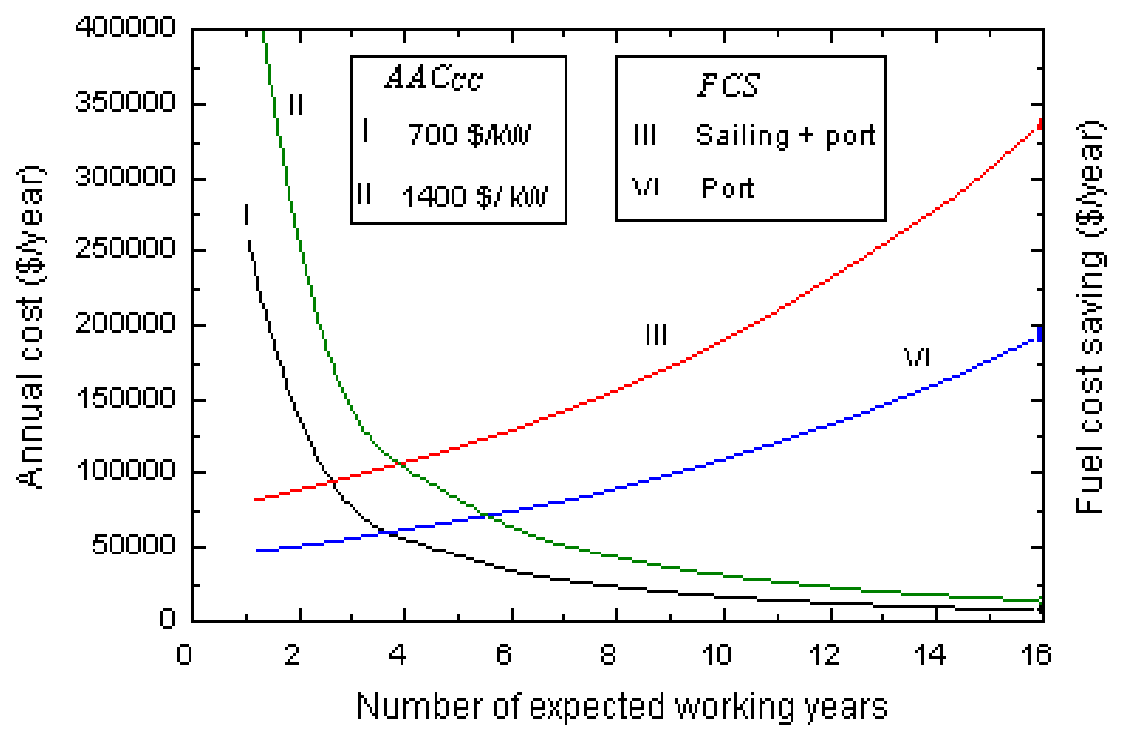

Fig. 5 Absorption air condition cost analysis for M/V Alkahera.

\section{ABSORPTION AIR CONDITION AND ENVIRONMENTAL ASPECTS}

It was shown by Liesbeth et al. (2009) and Eyring et al. (2009) that emissions from ships have been contributing substantially to air pollution in port cities including increased concentrations of Sulfur Oxide $\left(\mathrm{SO}_{\mathrm{X}}\right)$, Nitrogen Oxides $\left(\mathrm{NO}_{\mathrm{X}}\right)$, Hydrocarbon (HC) and different fractions of particular matters (PM), taking into consideration that coastal areas and port cities often have high population densities. Moreover, Riffat and Guoquan (2004) reported that there is environment risks result from leaking of Hydrochlorofluoro (HCF) that produced from compression vapor units, causing depletion of the ozone layer. Both exhaust gas emissions and HCF leaking problems may be finding a way for solution by applying AAC unit. For the primary estimations, assuming that the exhaust gases emission being exactly the limit value of the International Maritime Organization (IMO) curve for $\mathrm{NO}_{\mathrm{X}}$, while taking into consideration that diesel engine isusing diesel oil of $1.0 \%$ sulfur; values of $\mathrm{NOx}$, SOx, P.M and HC emissions factors are 10.5, 4.1, 0.3 and $0.53(\mathrm{~g} / \mathrm{kWh})$ respectively (Einang and MARINTEK, 2007; Woodyard, 2004). To evaluate the importance of AAC unit from the view point of environment; quantity of ship's emissions that could be reduced in case of applying AAC may be estimated from the following equation.

$$
E=\left(L_{E S} \cdot t_{s}+L_{E p} \cdot t_{p}\right) E_{f} \cdot 10^{-6}
$$

where $(E)$ and $\left(E_{f}\right)$ are emission quantity in (tons per year) and emission factor in $(g / k W h)$, respectively. Moreover, related to $\mathrm{CO}_{2}$ emission, in 2008, Marine Environmental Prevention Committee (MEPC) 57 addressed some of the issues set, one of these issues was a proposal for mandatory $\mathrm{CO}_{2}$ design index for ships, which was renamed as the Energy Efficiency Design Index (EEDI) at MEPC 58. It shows the importance of auxiliary engines as well as main engines as a source of emissions for a particular ship design (Kristensen, 2009). However, till now there is no limit for this index which may show a new modification in the coming years, but at any account it mainly depends on the energy efficient onboard ships which can be achieved through the management and the conservation of energy by various scenarios such as AACUs. It was shown by Woodyard (2004) that from modeling diesel engines emissions, value of emitted $\mathrm{CO}_{2}$ emission factor is about $0.645 \mathrm{~kg} / \mathrm{kWh}$. The results obtained from the previous equation indicate that there is a considerable amount of annual ship's emissions; $\mathrm{SO}_{\mathrm{X}}$, $\mathrm{NO}_{\mathrm{X}}, \mathrm{P} . \mathrm{M}$ and $\mathrm{HC}$ and a huge amount of $\mathrm{CO}_{2}$ could be eliminated in case of applying AAC unit as shown in Fig. (6). The figure shows the environmental benefits due to applying of the proposed system onboard M/V Alkahera during berthing condition, sailing condition, and sailing \& berthing condition together. Farther more, it shows that the proposed system could provide a reduction in $\mathrm{CO}_{2}, \mathrm{HC}, \mathrm{P} . \mathrm{M}, \mathrm{NOx}$ and SOx emissions by about 176,600, 142.66, 80.6, 2821 and $1001.6 \mathrm{~kg}$ per year, respectively. 


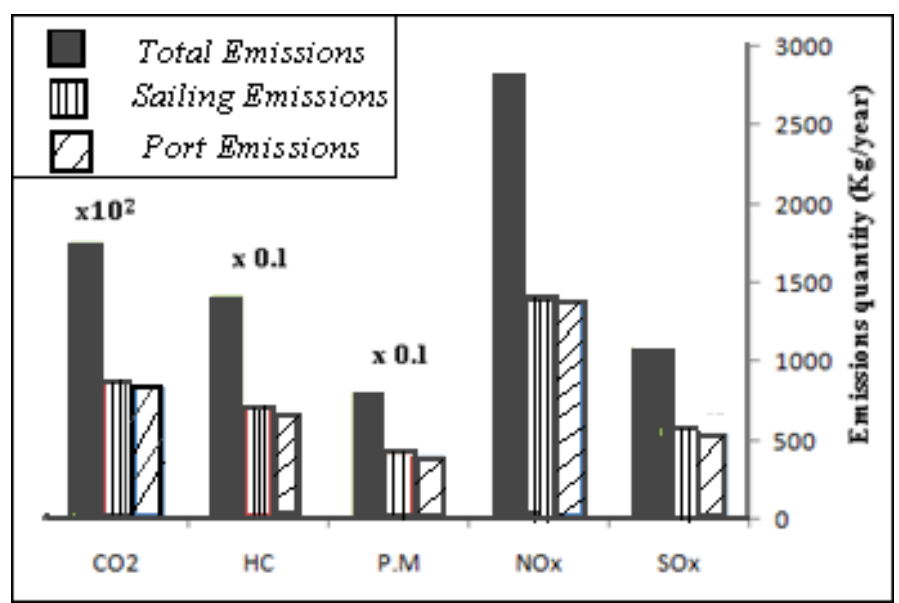

Fig. 6 Ship's annual emissions reduction quantity in case of AAC unit.

Although those quantities are little compared to the total ship's emissions, it still presents a valuable result in the way of marine air pollution reduction, sought by Marine Air Pollution (MARPOL) convention 1978/95 Annex VI and it's amended. In addition, Table 6 summarizes the differences between the sailing and ship's berthing conditions from view point of fuel cost saving and the reduction in emissions' quantity in case of applying the proposed system onboard M/V Alkahera.

Table 6 The difference between the proposed system's performance in sailing and berthing conditions.

\begin{tabular}{|c|c|c|c|c|c|c|}
\hline \multirow{2}{*}{ Ship condition } & \multirow{2}{*}{$\begin{array}{c}\text { Fuel cost saving } \\
\text { @ } \mathrm{n}=16(\text { \$ } / \text { year })\end{array}$} & \multicolumn{5}{|c|}{ Emissions reduction $(\mathrm{kg} /$ year $)$} \\
\cline { 3 - 7 } & 143,360 & 89,000 & 71.7 & 40.6 & 1,421 & 555 \\
\hline Sailing & 194,020 & 87,600 & 70.66 & 40.0 & 1,400 & 546.6 \\
\hline Berthing & &
\end{tabular}

Moreover, to verify the importance of the proposed system, Table 7 presents a comparison between the proposed system and the conventional system regards the system's performance and economic and environmental issues in all operating condition.

Table 7 A comparison between the conventional and proposed system's characteristics.

\begin{tabular}{|c|c|c|c|c|c|c|c|}
\hline \multicolumn{2}{|c|}{ System } & $\begin{array}{c}\text { Operating } \\
\text { cost }\end{array}$ & $\begin{array}{c}\text { Maintenance } \\
\text { activities }\end{array}$ & $\begin{array}{c}\text { Life } \\
\text { time }\end{array}$ & Emissions & Re-starting & $\begin{array}{c}\text { During } \\
\text { maneuvering }\end{array}$ \\
\hline \multicolumn{2}{|c|}{ Conventional system } & High & High & Short & High & Easy & Stable \\
\hline \multirow{2}{*}{$\begin{array}{c}\text { Proposed } \\
\text { system }\end{array}$} & Sailing & Low & Low & Long & Low & Need time & Unstable \\
\cline { 2 - 8 } & Berthing & Low & Low & Long & $\begin{array}{c}\text { Low\& more } \\
\text { effective }\end{array}$ & Need time & - \\
\hline
\end{tabular}

\section{CONCLUSIONS}

Recently, maritime transport industry has been facing many problems including both the economical aspect represented in the increase of fuel prices, and the environmental aspect represented in the laws issued by the International Maritime Organization (IMO), aiming to reduce pollutants emitted from ships. The work presented in this paper proposed a technique to operate an air conditioning absorption unit using the heat gained from the exhaust gases, either from the main engines during ship sailing, or by main electric generator during ship berthing. As a numerical example, the proposed technique has been applied on a high-speed craft that operates in the Red Sea between Egypt and Kingdom of Saudi Arabia. Engineering Equation Solver computer program was used to evaluate the viability of the proposed technique. Some considerations related to applying that 
proposal were explained. The results obtained were valuable from the view point of economic and environment issues especially with the increment of fuel prices and the new IMO legislations.

\section{ACKNOWLEDGEMENTS}

Special thanks are due to all the companies that provided essential information. Great appreciation to Prof. Mohamed Teamah, (Arab Academy for Science \& Technology and Maritime Transport) and prof. Mohamed El-Gohary, (King Abdul-Aziz University- Kingdom of Saudi Arabia), for their valuable assistance.

\section{REFERANCES}

ASHRAE, 1997. Handbook: Fundamentals. Publisher Atlanta, GA.

ASHRAE, 2010. Handbook-refrigeration. I.P. Ed.

Banawan, A.A., El Gohary, M.M. and Seddiek, I.S., 2010. Environmental and economical benefits of changing from marine diesel oil to natural-gas fuel for short-voyage high-power passenger ships. Journal of Engineering for the Maritime Environment, 224(M2), pp.103-113.

Bergman, T.L., Lavine, A.S., Incropera, F.P. and Dewitt, P., 2011. Fundamentals of heat and mass transfer. $7^{\text {th }}$ Ed. ISBN 13 978-0470-50197-9. John Wiley \& Sons.

Bunker world, 2012. Bunker world Prices. [online] Available at: $<$ http://www.bunkerworld.com/home/about $>$ [Accessed 3 May 2012].

Carrier company, 2012. 16LJ Single-effect, low temperature hot water hermetic absorption liquid chiller. Catalog No. 0452160003-01, printed in USA. [online] Available at: <http://www.findthatpdf.com/search-31037362-hPDF/downloaddocuments-161j-1pd.pdf.htm>. [Accessed 14 February 2012].

Corbett, J.J.; Wang, H. and Winebrake, J.J., 2009. The effectiveness and costs of speed reductions on emissions from international shipping. Transportation Research Part D: Journal of Transport and Environment, [e-journal] 14(8), pp. 593598, Available through: King Abdul-Aziz University Library website $<\mathrm{http}$ ///library.kau.edu.sa $>$ [Accessed 28 March 2012].

CHP Application Center, 2011. Beloit Memorial Hospital Case Study. Technical report [pdf] Available at: <http://www. chpcentermw.org/pdfs/toolkit/cs_bmh.pdf $>$ [Accessed 15 March 2011].

De Lucas, A., Donate, M., Molero, C., Villasenor, J. and Rodriguez, J., 2004. Performance evaluation and simulation of a new absorption for an absorption refrigeration system. International Journal of Refrigeration, [e-journal] 27, pp.324330, Available through: King Abdul-Aziz University Library website <http://library.kau.edu.sa $>$ [Accessed 19 November 2011].

Det Norsek Veritas, 2000. Rules for high speed, light craft and naval surface craft. July 2000, amended 2011 .Part 6, Chapter 9.

Domkundwar, M., 2004. A course in internal combustion engines. $2^{\text {nd }}$ Ed. DhanpatRai\& Co. (P) Ltd, New Delhi.

Elsafty, A. and Al-Daini, A.J., 2002. Economical comparison between a solar powered vapor absorption air-conditioning system and a vapor compression system in the Middle East. Journal of Renewable energy, [e-journal] 25(4), pp.569583, Available through: King Abdul-Aziz University Library website <http://library.kau.edu.sa $>$ [Accessed 6 May 2012].

Einang, M.M. and MARINTEK, 2007. Gas fuelled ships. $25^{\text {th }}$ CIMAC conference. 21-24 May 2007. Vienna: Norway.

Eyring, V., Isaksen, I.S., Berntsen, T., Collins, W.J., Corbett, J.J., Endresen, O., Grainger, R.G., Moldanova, J., Schlager, H. and Stevenson, D.S., 2009. Transport impacts on atmosphere and climate: Shipping. Atmospheric Environment, doi: 10.1016/j.atmosenv.2009.04.059.

Florides, G.A., Kalogirou, S.A., Tassou, S.A. and Wrobel, L.C., 2003. Design and construction of Li-Br-water absorption machine. Journal of Energy conservation and management, [e-journal] 44, pp.2483-2508, Available through: King Abdul-Aziz University Library website <http://library.kau.edu.sa $>$ [Accessed 27 October 2011].

Hall, J., 2010. Assessment of $\mathrm{CO}_{2}$ and priority pollution reduction by installation of shore side power. Journal of Resource, Conservation and Recycling, [e-journal] 54, pp.462-467, Available through: King Abdul-Aziz University Library website <http://library.kau.edu.sa $>$ [Accessed 18 April 2012]. 
Harbach, J., 2005. Marine refrigeration \& air condition. Publisher Tidewater, ISBN 0870335650.

Holman, J., P., 2002. Heat Transfer. $9^{\text {th }}$ Ed. McGraw-Hill publication, ISBN 0-07-240655-0.

Hunt, E.C. and Butman, B.S., 1995. Marine engineering economical and cost analysis. Cornell maritime press, centreville, Mary land.

Kaynakli, O. and Kilic, M., 2007. Theoretical study on the effect of operating conditions on performance of absorption refrigeration system. Journal of Energy Conservation and Management, [e-journal] 48, pp.599-607, Available through: King Abdul-Aziz University Library website <http://library.kau.edu.sa $>$ [Accessed 15 January 2012].

Kristensen, P., 2009. The development of the energy efficiency design index. $29^{\text {th }}$ Motor ship Conference, session 2,26 May 2009, Copenhagen: Denmark.

Liesbeth, S.A., Vlieger, A., Panis, A. and Cosimo, C.B., 2009. Emissions of maritime transport: A European reference system. Pastorib Science of the Total Environment, [e-journal] 408, pp.318-323, Available through: King Abdul-Aziz University Library website $<$ http://library.kau.edu.sa $>$ [Accessed 23 February 2012].

Manzela, A.A., Hanriot, S.M., Gomez, L.C. and Sodre, J.R., 2010. Using engine exhaust gas as energy source for an absorption refrigeration system. Journal of Applied Energy, [e-journal] 87, pp.1141-1148, Available through: King AbdulAziz University Library website $<$ http://library.kau.edu.sa $>$ [Accessed 10 September 2011].

Masheiti, S. and Agnew, B., 2010. Thermodynamic simulation modeling of low- temperature geothermal source located in Arid-Zone area North Africa. Jordan Journal of Mechanical and Industrial Engineering, 4(1), pp.61-68.

Munk, T., 2006. Fuel conservation through managing hull resistance. Motor ship Propulsion Conference. 26 April 2006, Copenhagen: Denmark.

M/V Alkahera, 2008. Sea trial book. Alkahera Company for Ferries and Maritime Transport, Alexandria, Egypt.

Notteboom, T.E. and Vernimmen, B., 2009. The effect of high fuel costs on liner service configuration in container shipping. Journal of Transport Geography xxx, [e-journal] 17(5), pp.325-337, Available through: King Abdul-Aziz University Library website <http://library.kau.edu.sa> [Accessed 3 August 2011].

Riffat, S.B. and Guoquan, Q., 2004. Comparative investigation of thermoelectric air-conditioners versus vapor compression and absorption air-conditioners. Journal of Applied Thermal Engineering, [e-journal] 24, pp.1979-1993, Available through: King Abdul-Aziz University Library website $<$ http://library.kau.edu.sa $>$ [Accessed 10 February 2012].

Seara, J., Vales, A. and Vázquez, M., 1998. Heat recovery system to power an onboard $\mathrm{NH}_{3}-\mathrm{H}_{2} \mathrm{O}$ absorption refrigeration plant in trawler chiller fishing vessels. Journal of Applied Thermal Engineering, [e-journal] 18(2), pp.1189-1205, Available through: King Abdul-Aziz University Library website <http://library.kau.edu.sa> [Accessed 26 October 2011].

Sdrubali, F. and Grignaffini, Q., 2005. Experimental evalution of the performance of a $\mathrm{H}_{2} \mathrm{O}-\mathrm{LiBr}$ absorption refrigeration under different service conditions. International Journal of Refrigeration, [e-journal] 28, pp.489-497, Available through: King Abdul-Aziz University Library website <http://library.kau.edu.sa $>$ [Accessed 10 April 2012].

Wang, S. and Wang, R., 2005. Recent developments of refrigeration technology in fishing vessels. Journal of Renewable Energy, [e-journal] 30(4), pp.589-600, Available through: King Abdul-Aziz University Library website $<$ http://library. kau.edu.sa> [Accessed 23 December 2011].

Wartsila, 2010. Ship power product catalogue. Technical report, 2nd Ed. Available at: <http://62.236.120.40/Wartsila/ 364383SPPC_2010_SE_Low.pdf> [Accessed 25 January 2012].

Woodyard, D., 2004. Pounder's Marine Diesel engines and gas Turbines. $8^{\text {th }}$ Ed. ISBN 075065846 0, Great Britain.

\section{APPENDIX (1)}

a- Exhaust gas mass flow rate calculation.

$$
\begin{aligned}
& \dot{m}_{g @ \theta_{p}}=\left[-5488 \theta_{p}{ }^{6}+20921 \theta_{p}{ }^{5}-31859 \theta_{p}{ }^{4}+24853 \theta_{p}{ }^{3}-10479 \theta_{p}{ }^{2}+2204 \theta_{p}+53.06\right] \cdot a \\
& a=(1+[A / F] \lambda) \frac{B H P_{\theta}}{3.6}\left(\text { Squared value }\left(R^{2}\right)=0.996\right)
\end{aligned}
$$


$\left(\theta_{p}\right)$ is engine load percentage, $\left(B H P_{@ \theta}\right)$ engine brake power at various engine loads, (Curve fits from data presented in ship's sea trial book), (M/V Alkahera, 2008). b-Exhaust gas properties at ( $\left.T_{1}\right)$ : Curve fits from data presented in (Bergman et al., 2011), at the related working pressure and temperature.

$$
\begin{aligned}
& P_{r_{i}}=(-9) \cdot 10^{-5} \cdot T_{1}+0.779 \\
& C_{p e x}=(0.13) \cdot T_{1}^{0.329} \\
& \mu_{i}=\left((-2) 10^{-7} \cdot T_{1}^{3}+0.0002 T_{1}^{2}+0.3307 T_{1}+33.619\right)(9.81) 10^{-7} \\
& K_{i}=\left((-9) 10^{-6} T_{1}^{2}+0.087 T_{1}-(9.115)\right) 10^{-3}
\end{aligned}
$$

\section{APPENDIX (2)}

The equations derived using the principle heat transfer equations (Holman, 2002). a-Through exhaust pipe from point (1) to point (2) Fig. 2.

$$
Q_{\text {flow }}=\frac{\Delta T_{\text {overall }}}{\sum R_{\text {th }}}
$$

( $\left.Q_{\text {flow }}\right)$ is heat flow through pipe (1-2), $\left(\Delta T_{\text {overall }}\right)$ is the difference temperature between $\left(T_{1}\right)$ and $\left(T_{a m b}\right)$, and $\left(R_{t h}\right)$ exhaust pipe's thermal resistance, expressed as:

$$
\sum R=\left[\left(\frac{1}{\pi d_{i} L h_{i}}\right)+\left(\frac{\ln \frac{r_{o}}{r_{i}}}{2 \pi L k_{p}}\right)+\left(\frac{\ln \frac{r_{s}}{r_{i}}}{2 \pi L k_{s}}\right)+\left(\frac{1}{\pi d_{o} L h_{o}}\right)\right]
$$

Also; $\left(Q_{\text {flow }}\right)$ may be expressed as:

$$
Q_{\text {flow }}=\left[\dot{m}_{g} C_{p g}\right]\left(T_{2}-T_{1}\right)
$$

Then;

$$
\left[\dot{m}_{g} C_{p g}\right]\left(T_{2}-T_{1}\right)=\frac{\left(T_{1}-T_{a m b}\right)}{\left[\left(\frac{1}{\pi d_{i} L h_{i}}\right)+\left(\frac{\ln \frac{r_{o}}{r_{i}}}{2 \pi L k_{p}}\right)+\left(\frac{\ln \frac{r_{s}}{r_{i}}}{2 \pi L k_{s}}\right)+\left(\frac{1}{\pi d_{o} L h_{o}}\right)\right]}
$$


Thus, $T_{2}$ may be expressed as:

$$
T_{2}=T_{1}-\frac{\left(T_{1}-T_{a m b}\right)}{\left[\dot{m}_{g} C_{p g}\right]\left[\left(\frac{1}{\pi d_{i} L h_{i}}\right)+\left(\frac{\ln \frac{r_{o}}{r_{i}}}{2 \pi L k_{p}}\right)+\left(\frac{\ln \frac{r_{s}}{r_{i}}}{2 \pi L k_{s}}\right)+\left(\frac{1}{\pi d_{o} L h_{o}}\right)\right]}
$$

equ. 1

b-Through heat exchanger from point (2) to point (3) and heat transfer between exhaust gases and water side, Fig. 2.

$$
\begin{aligned}
& Q=\dot{m}_{g} C_{p g}\left(T_{2}-T_{3}\right)=\dot{m}_{w} C_{p w}\left(T_{7}-T_{5}\right) \\
& Q=Q_{\max } \cdot \varepsilon \\
& Q_{\max }=\dot{m}_{g} C_{p g}\left(T_{2}-T_{5}\right)
\end{aligned}
$$

$(Q)$ is heat transferred from the hot stream to the cold stream, and $\left(Q_{\max }\right)$ is the maximum heat transfer in a heat exchanger of any configuration.

Then:

$$
\begin{aligned}
& Q=\dot{m}_{g} C_{p g}\left(T_{2}-T_{3}\right)=\dot{m}_{w} C_{p w}\left(T_{7}-T_{5}\right) \\
& {\left[\frac{\dot{m}_{g} C_{p g}}{\dot{m}_{w} C_{p w}}\right]\left(T_{2}-T_{5}\right) \varepsilon=\left(T_{7}-T_{5}\right)} \\
& R_{c} \cdot\left(T_{2}-T_{5}\right) \varepsilon=\left(T_{7}-T_{5}\right) \\
& T_{7}=R_{c} \varepsilon\left(T_{2}-T_{5}\right)+T_{5} \quad \text { equ. } 4
\end{aligned}
$$

